\title{
ANALISIS POLA KONSUMSI RUMAH TANGGA PETANI KELAPA SAWIT DI KABUPATEN LABUHANBATU
}

\section{ANALYSIS OF CONSUMPTION PATTERN OF PALM OIL FARMERS IN LABUHANBATU DISTRICT}

\author{
Zulkarnain Nasution ${ }^{1}$, Khairul Rizal ${ }^{2}$, Junita Lubis ${ }^{3}$ \\ Universitas Labuhanbatu ${ }^{1,2,3}$ \\ zulkarnainnasution1974@gmail.co.id
}

\begin{abstract}
The household is the smallest unit in society, so it can be said that household income means community income. This study aims to determine the determination of the variable income, economic activity, and household members, as well as differences in the location of residence to the consumption of oil palm farmers in Labuhanbatu Regency. The method used to analyze data with multiple linear regression models, by certifying in the Least Square Dummy Variable (LSDV) method. The estimation results found that all independent variables were positive and significantly influenced the amount of food consumption, on the contrary were negative and significant towards non-food consumption expenditure. The estimation results also found that the amount of consumption of various types of foodstuffs in urban communities was smaller than the food consumption of inland communities amounting to Rp.1,248,000. However, greater than the consumption of food for coastal communities is Rp. 1,323,800. While the amount of consumption expenditure for various types of non-food for urban communities is greater than non-food consumption for inland communities Rp.2,782,000. And also greater than non-food consumption of coastal communities, namely Rp. 3776 000. Variation in the ability of independent variables in explaining food consumption by 92.5 percent, and expenditure for non-food consumption by 87.4 percent. The model specification is very good with the model being free from violations of the classical assumptions of multicollinearity and heterokedastisitas.
\end{abstract}

Keywords: Consumption, Income, Socio-economy, Oil palm Farmers

\begin{abstract}
ABSTRAK
Rumah tangga merupakan unit terkecil dalam masyarakat, jadi dapat dikatakan bahwa pendapatan rumah tangga berarti pendapatan masyarakat. Penelitian ini bertujuan untuk mengetahui determinasi variabel pendapatan, aktivitas ekonomi, dan anggota rumah tangga, juga perbedaan lokasi tempat tinggal terhadap konsumsi petani kelapa sawit di Kabupaten Labuhanbatu. Metode yang digunakan untuk menganalisis data dengan model regresi linier berganda, dengan mensifikasi dalam metode Least Square Dummy Variabel (LSDV). Hasil estimasi menemukan semua variabel bebas bertanda positif dan signifikan mempengaruhi besarnya konsumsi makanan, sebaliknya bertanda negatif dan signifikan terhadap pengeluaran konsumsi bukan makanan. Hasil estimasi juga menemukan besarnya konsumsi berbagai jenis bahan makanan masyarakat perkotaan lebih kecil dari konsumsi makanan masyarakat pedalaman sebesar Rp.1.248.000. Namun lebih besar dari konsumsi bahan makanan masyarakat pesisir yaitu
\end{abstract}


Rp.1.323.800. Sementara besarnya pengeluaran konsumsi berbagai jenis bukan makanan masyarakat perkotaan lebih besar dari konsumsi bukan makanan masyarakat pedalaman Rp.2.782.000. Dan juga lebih besar dari konsumsi bukan makanan masyarakat pesisir yaitu Rp.1.376 000. Variasi kemampuan variabel bebas dalam menjelaskan konsumsi makanan sebesar 92,5 persen, dan pengeluaran konsumsi bukan makanan sebesar 87,4 persen. Spesifikasi model sudah sangat baik dengan terbebasnya model dari pelanggaran asumsi klasik multikolinieritas dan heterokedastisitas.

Kata Kunci: Konsumsi, Pendapatan, Sosial-ekonomi, Petani Kelapa Sawit

\section{PENDAHULUAN}

Perilaku konsumsi masyarakat menunjukkan perilaku masyarakat dalam jangka panjang terhadap alokasi pendapatannya untuk melakukan konsumsi yang di dalamnya meliputi berapa besar pendapatan mereka yang dialokasikan untuk konsumsi dan pola hasrat untuk mengkonsumsi. Dalam usaha mengalokasikan pendapatannya untuk konsumsi tersebut, konsumen akan dihadapkan pada proses membuat keputusan terhadap produk atau jasa yang akan dikonsumsi untuk memenuhi kebutuhan hidup sekaligus mencapai kepuasan.

Pada kondisi inilah sebenarnya perilaku konsumen sudah mulai berjalan. Sehingga perilaku beli konsumen atau disebut perilaku konsumen,bukanlah suatu perkara kecil karena setiap anggota masyarakat merupakan konsumen. Pola konsumsi sangat dipengaruhi oleh perilaku konsumsi konsumen dalam jangka panjang. Perilaku konsumsi konsumen ini yang akan dijadikan dasar dalam mencari pola konsumsi saat ini. Pola konsumsi masyarakat ini pada akhirnya akan berpengaruh pada kondisi ekonomi makro, seperti pendapatan masyarakat (Hanum, 2017).

Pola konsumsi mencerminkan pemilahan konsumsi oleh konsumen. Perilaku konsumsi konsumen ini yang akan dijadikan dasar dalam mencari pola konsumsi saat ini. Adapun faktorfaktor yang mempengaruhi pola konsumsi, diantaranya: Tingkat pendapatan masyarakat, selera konsumen, setiap orang memiliki keinginan yang berbeda dan ini akan mempengaruhi pola konsumsi. Konsumen akan memilih satu jenis barang untuk dikonsumsi dibandingkan jenis barang lainnya. Harga barang, jika harga suatu barang mengalami kenaikan, maka konsumsi barang tersebut akan mengalami penurunan. Sebaliknya jika harga suatu barang mengalami penurunan, maka konsumsi barang tersebut akan mengalami kenaikan. Kaitan konsumsi dengan harga barang dapat dibedakan apakah barang tersebut bersifat substitusi (barang substitusi adalah barang yang dapat menggantikan fungsi barang lainnya) atau komplementer (barang komplementer adalah barang yang melengkapi fungsi barang lainnya) (Prasetyoningrum et al., 2016).

Rumah tangga merupakan unit terkecil dalam masyarakat, jadi dapat dikatakan bahwa pendapatan rumah tangga berarti pendapatan masyarakat. Pendekatan konsumsi merupakan salah satu pendekatan yang sering digunakan untuk menganalisa berapa besarnya pendapatan rumah tangga petani. Pendapatan tersebut pada akhirnya akan mempengaruhi pola konsumi dari masing-masing rumah tangga tersebut. Rumah tangga membuat keputusan untuk mengalokasikan sebagian anggarannya untuk membeli pangan dan kebutuhan non pangan.

Salah satu tujuan ekonomi adalah untuk menjelaskan dasar-dasar 
prilaku konsumen. Pendalaman tentang hukum permintaan dan mengetahui bahwa orang cenderung membeli lebih banyak barang, apabila harga barang itu rendah, begitu sebaliknya. Dasar pemikirannya tentang prilaku konsumen bahwa orang cenderung memilih barang dan jasa yang nilai kegunaannya paling tinggi (Wahyuni, 2013).

Banyak faktor yang menentukan permintaan konsumsi atau pengeluaran individu atas barang-barang dan jasajasa dalam suatu perekonomian. Faktor tersebut diantaranya adalah pendapatan disposibel yang merupakan faktor utama, banyaknya anggota keluarga, usia dari anggota keluarga, pendapatan yang terdahulu dan pengharapan akan pendapatan dimasa yang akan datang (Wahyuni, 2013).

Kelompok berpenghasilan tinggi mempunyai kecenderungan mengkonsumsi rata-rata (average propensity to consume) yang lebih kecil daripada kelompok masyarakat berpenghasilan rendah. Rumah tangga miskin pada umumnya mengeluarkan pendapatannya lebih besar untuk kebutuhan dasar, baik yang terdiri dari kebutuhan maupun konsumsi individu (makanan, pakaian, perumahan) maupun keperluan pelayanan sosial tertentu (air minum, sanitasi, transportasi, kesehatan dan pendidikan). Pendapatan adalah jumlah penghasilan yang diterima oleh penduduk atas prestasi kerjanya selama satu periode tertentu, baik harian, mingguan, bulanan ataupun tahunan. Beberapa klasifikasi pendapatan antara lain: 1) Pendapatan pribadi, yaitu; semua jenis pendapatan yang diperoleh tanpa memberikan suatu kegiatan apapun yang diterima penduduk suatu Negara. 2) Pendapatan disposibel, yaitu; pendapatan pribadi dikurangi pajak yang harus dibayarkan oleh para penerima pendapatan, sisa pendapatan yang siap dibelanjakan inilah yang dinamakan pendapatan disposibel. 3) Pendapatan nasional, yaitu; nilai seluruh barang-barang jadi dan jasa-jasa yang diproduksikan oleh suatu Negara dalam satu tahun (Tamawiwi et al., 2015).

Petani kebun sawit rakyat adalah petani kebun sawit yang bersifat individu. Perkembangan yang ada di dalam usaha perkebunan kelapa sawit rakyat swadaya ini, menjadi menarik karena selama ini anggapan bahwa perkebunan rakyat dicirikan oleh berbagai kelemahan antara lain: diusahakan di lahan relatif sempit dengan cara tradisional, produktivitas dan mutu rendah, posisi dalam pemasaran hasil lemah. Sebaliknya, perkebunan besar diusahakan secara modern, dengan teknologi maju.

Tanaman perkebunan yang akan dikembangkan melalui program revitalisasi ini salah satunya adalah kelapa sawit. Program revitalisasi perkebunan ini bertujuan untuk mempercepat pertumbuhan sektor riil, khususnya meningkatkan kesempatan kerja, pendapatan masyarakat, daya saing melalui pengembangan industri hilir berbasis perkebunan dan meningkatkan penguasaan ekonomi nasional serta pengembangan wilayah.

Penelitian ini di dasarkan pada penelitian terdahulu yang juga pernah meneliti tentang pola konsumsi rumah tangga seperti Prasetyoningrum (2016) meneliti pola konsumsi rumah tangga petani jagung, Mayasari et al., (2018) yang meneliti pola konsumsi pangan di Jawa Timur, dan Yusti et al., (2014) meneliti pola konsumsi ubi kayu dan olahannya. Untuk itu, perbedaan dari penelitian ini adalah pada objek penelitiannya dimana pola konsumsi di terapkan pada petani kelapa sawit. 


\section{METODE PENELITIAN}

\section{Lokasi Penelitian}

Lokasi penelitian diambil secara sengaja, yaitu di Kabupaten Labuhanbatu. Kabupaten Labuhanbatu dipilih karena salah satu yang memiliki luas perkebunan kelapa sawit terluas di Provinsi Sumatera Utara. Sampel adalah sebagian dari jumlah dan karakteristik yang dimiliki oleh populasi tersebut. Sampel penelitian ini adalah petani kelapa sawit yang memiliki luas lahan di bawah 10 hektar, jumlah sampel yang diambil adalah 77 petani kelapa sawit Daerah Labuhanbatu.

\section{Metode Analisis}

Populasi dalam penelitian ini adalah semua rumah tangga masyarakat yang menetap di pedesaan dengan mata pencaharian di sub sektor perkebunan kelapa sawit serta penduduk yang menetap di perkotaan. Pemilihan rumah tangga sampel untuk menjadi responden dari populasi yang ada ditentukan secara two stage cluster sampling. Pada tahap pertama ditingkat kabupaten diterapkan 9 kecamatan sampel secara berimbang yaitu cluster desa pesisir, perkotaan dan cluster desa pedalaman di Kabupaten Labuhanbatu. Pada tahap kedua menetapkan masing-masing 2 desa dalam satu kecamatan. Dari setiap kecamatan ini ditetapkan 9 dan 10 rumah tangga sampel dengan pembagian sesuai populasi pemilik kebun kelapa sawit dengan luas di bawah $10 \mathrm{Ha}$, dan dengan mempertimbangkan batas minimum dan maksimum sampel dari masing-masing desa yang ada di dalamnya, sehingga didapat seluruhnya 77 rumah tangga sampel.

\section{Model Analisis}

Estimasi berbagai jenis
pengeluaran konsumsi $(K)$ pada
penelitian yang akan dilakukan ini

digunakan metode OLS (Ordinary Least Square) dengan model regresi linear berganda yang diadopsi dari model Kautsoyiannis (1977), Domowitz dan Elbadawi (1987), Nachrowi dan Usman (2002), Lains (2006) yaitu:

$Y=a+b_{1} X_{1}+b_{2} X_{2}+\ldots \ldots \ldots . .+b_{n} X_{n}+\mu$

Dengan mensubstitusi pengeluaran konsumsi makanan $\left(K_{M K}\right)$ dan konsumsi bukan makanan $\left(K_{B M K N}\right)$ sebagai dependen variabel dan variabel independen serta variabel boneka $(D)$ ke dalam model, maka didapat model penelitian ini sebagai berikut:

Model 1:

$K_{\text {MKN }}=b_{0}+b_{1} P D P T+b_{2} A K E++b_{3} A R T+c_{1} D_{1}+c_{2} D_{2}+\mu$

Model 2:

$K_{\text {BUKN }}=b_{0}+b_{1} P D P T+b_{2} A K E+b_{3} A R T+c_{1} D_{1}+c_{2} D_{2}+\mu$

Dimana:

$K_{M K N}=$ Pengeluaran konsumsi berbagai jenis makanan (diukur dalam satuan rupiah).

$K_{B M K N}=$ Pengeluaran konsumsi bukan makanan (diukur dalam satuan rupiah).

$P D P T=$ Pendapatan rumah tangga (diukur dalam satuan rupiah).

$A K E=$ Aktivitas ekonomi kepala keluarga (diukur dalam satuan jam kerja).

$A R T=$ Jumlah anggota rumah tangga (diukur dalam satuan orang).

$D_{1} \quad=$ Variabel dummi untuk lokasi tempat tinggal di kota; diberi kode 1 untuk observasi 1-60, sedang daerah lain diberi kode 0 .

$D_{2} \quad=$ Variabel dummi untuk lokasi tempat tinggal di desa pedalaman; diberi kode 1 untuk observasi 61120 , sedang daerah lain diberi kode 0 .

$\begin{array}{lll}b_{0} & = & \text { Intersep (konstanta) } \\ b_{1}-b_{3} & =\quad \text { Parameter regresi. } \\ \mu & =\quad \text { Kesalahan pengganggu } \\ & \text { (disturbance) }\end{array}$




\section{HASIL DAN PEMBAHASAN}

Tabel 1 Jumlah Penduduk dan Jumlah Keluarga, Mata Pencarian Dan Kepadatan Penduduk PerKecamatan Kabupaten Labuhanbatu

\begin{tabular}{|c|c|c|c|c|c|c|c|c|c|}
\hline \multirow{2}{*}{$\begin{array}{c}\text { URAIAN } \\
\text { 1. Total penduduk }\end{array}$} & \multicolumn{9}{|c|}{ Kecamatan } \\
\hline & $\begin{array}{c}\text { Ranta } \\
\text { u } \\
\text { Utara }\end{array}$ & $\begin{array}{c}\text { Rantau } \\
\text { Selata } \\
\text { n }\end{array}$ & $\begin{array}{l}\text { Bilah } \\
\text { Hulu }\end{array}$ & $\begin{array}{l}\text { Bilah } \\
\text { Barat }\end{array}$ & $\begin{array}{c}\text { Pangka } \\
\text { tan }\end{array}$ & $\begin{array}{l}\text { Bilah } \\
\text { Hilir }\end{array}$ & $\begin{array}{l}\text { Panai } \\
\text { Hulu }\end{array}$ & $\begin{array}{l}\text { Panai } \\
\text { Hilir }\end{array}$ & $\begin{array}{c}\text { Panai } \\
\text { Teng } \\
\text { ah }\end{array}$ \\
\hline Laki-laki & 48906 & 39453 & $\begin{array}{r}3195 \\
2 \\
\end{array}$ & $\begin{array}{r}2035 \\
5 \\
\end{array}$ & 17179 & 26853 & $\begin{array}{r}1988 \\
2 \\
\end{array}$ & $\begin{array}{r}1917 \\
6 \\
\end{array}$ & $\begin{array}{r}2073 \\
9 \\
\end{array}$ \\
\hline Perempuan & 49336 & 38752 & $\begin{array}{r}3166 \\
3 \\
\end{array}$ & $\begin{array}{r}1968 \\
7 \\
\end{array}$ & 16793 & 25695 & $\begin{array}{r}1926 \\
0 \\
\end{array}$ & $\begin{array}{r}1840 \\
0 \\
\end{array}$ & $\begin{array}{r}1983 \\
7 \\
\end{array}$ \\
\hline 2. Jumlah KK & 18682 & 18497 & $\begin{array}{r}1510 \\
6 \\
\end{array}$ & 8116 & 8104 & 12351 & 8074 & 7776 & 7711 \\
\hline \multicolumn{10}{|l|}{ 3. Mata Pencarian } \\
\hline Petani & 6,19 & 64,45 & 75,7 & 84,78 & 82,71 & 59,23 & $42,17 \quad 7$ & 74,29 & 81 \\
\hline Industri & 12,18 & 3,12 & 6,71 & 15,09 & 6,71 & 1,77 & 16,96 & 0,41 & 1,15 \\
\hline PNS/POLRI/TNI & 11,68 & 02.47 & 0,35 & 9,89 & 0,35 & 1,83 & 13.20 & 1 & 15.36 \\
\hline - Lainnya & 60,55 & 29,96 & 17,33 & 35,67 & 17,33 & 37,46 & 27,66 & 24,3 & 16,21 \\
\hline $\begin{array}{l}\text { 4. Kepadatan } \\
\text { penduduk (per } \mathrm{Km}^{2} \text { ) }\end{array}$ & 873 & 1215 & 217 & 193 & 96 & 119 & 147 & 111 & 84 \\
\hline \multicolumn{10}{|c|}{ Sumber : Data olahan (2020) } \\
\hline \multicolumn{4}{|c|}{$\begin{array}{l}\text { Kondisi sosial ekonomi } \\
\text { masyarakat masyarakat Labuhanbatu } \\
\text { yang dijadikan sampel penelitian ini } \\
\text { meliputi; umur kepala rumah tangga, } \\
\text { jenis kelamin, status perkawinannya, } \\
\text { pekerjaan (utama dan sampingan), } \\
\text { pendapatan, bahkan sampai kepada } \\
\text { kondisi rumah yang digunakan sebagai } \\
\text { tempat tinggal. Gambaran tentang } \\
\text { kondisi sosial ekonomi masyarakat } \\
\text { miskin yang dijadikan sampel penelitian } \\
\text { ini akan dibahas per karakter. Sehingga }\end{array}$} & \multicolumn{6}{|c|}{$\begin{array}{l}\text { diharapkan akan didapat } \\
\text { gambaran suatu } \\
\text { kehidupan masyarakat petani } \\
\text { sawit Kabupaten Labuhanbatu. } \\
\text { Sebagaimana rumusan } \\
\text { regresi linier berganda dengan } \\
\text { memasukkan Least Square } \\
\text { Variabel (LSDV) dengan variabel } \\
\text { dependen konsumsi berbagai jenis } \\
\text { makanan. Hasil estimasi terhadap } \\
\text { model, dijumpai: }\end{array}$} \\
\hline \multicolumn{10}{|c|}{ Tabel 2 Hasil Estimasi Model Konsumsi Makanan } \\
\hline VARIABEL & FISIEN & STA & DAR & RROR & & IITUNG & SIGNI & IFIKA] & NSI \\
\hline Konstanta & 1390,396 & & & $1267,4 c$ & & $-6,424$ & & 0,156 & \\
\hline PDPT & 0,624 & & & 0,02 & & 17,845 & & 0,0 & \\
\hline AKE & 125,121 & & & 89,28 & & 2,782 & & 0,045 & \\
\hline ART & 6214,256 & & & 3124,3 & & 3,078 & & & \\
\hline D1 & 7891,854 & & & 7345 & & 1,519 & & & \\
\hline D2 & 2156,336 & & & 8924,95 & & 3,836 & & 0,013 & \\
\hline
\end{tabular}

Variabel Dependen: KMKN

Sumber : Data Olahan (2020) 
Berdasarkan model tersebut di atas, dijumpai besarnya nilai konstanta 31390,396 berarti bahwa dengan asumsi variabel lain tidak ada (nol), besarnya konsumsi berbagai jenis bahan makanan masyarakat perkotaan lebih kecil dari konsumsi makanan masyarakat pedalaman Rp.1.248.000. Namum lebih besar dari konsumsi bahan makanan masyarakat pesisir sebesar Rp.1.323.800. Konsumsi makanan masyarakat pedalaman sebesar Rp.2.546,340. Hal ini mengindikasikan bahwa konsumsi bahan makanan masyarakat perkotaan lebih kecil dibandingkan masyarakat yang tinggal di wilayah pedalaman, namun masih lebih besar dibanding masyarakat pesisir Kabupaten Labuhanbatu.

Koefisien variabel pendapatan (PDPT) sebesar 0,624 yang berarti bahwa kenaikan pendapatan Rp.1.000 akan meningkatkan pengeluaran konsumsi untuk jenis bahan makanan sebesar Rp.624. Koefisien variabel aktivitas ekonomi (AKE) sebesar 125,121 yang berarti bahwa dengan bertambahnya 1 jam waktu kerja dalam 1 bulan akan menyebabkan bertambahnya pengeluaran konsumsi bahan makanan sebesar Rp.125,121. Demikian halnya dengan anggota rumah tangga (ART) dijumpai koefisien sebesar 6214,256 yang berarti bahwa dengan bertambahnya anggota keluarga 1 orang, akan menambah pengeluaran konsumsi bahan makanan sebesar Rp.6214.256 yang menyebabkan bertambahnya beban pengeluaran keluarga.

\section{Model Pengeluaran Konsumsi Bukan Makanan}

Sebagaimana rumusan model regresi linier berganda dengan memasukkan Least Square Dummy Variabel (LSDV) dengan variabel dependen pengeluaran untuk bukan makanan. Hasil estimasi terhadap model, dijumpai :

Tabel 3 Hasil Estimasi Model Pengeluaran Bukan Makanan

\begin{tabular}{crrrr}
\hline VARIABEL & KOEFISIEN & \multicolumn{1}{c}{$\begin{array}{c}\text { STANDAR } \\
\text { ERROR }\end{array}$} & T-HITUNG & SIGNIFIKANSI \\
\hline Konstanta & 31390,396 & 1267,460 & 6,424 & 0,156 \\
PDPT & $-0,523$ & 0,025 & 10,845 & 0,001 \\
AKE & $-125,121$ & 89,284 & $-2,782$ & 0,045 \\
ART & $-6214,256$ & 3124,346 & $-3,078$ & 0,014 \\
D1 & $-7891,854$ & 7345,870 & $-1,519$ & 0,021 \\
D2 & $-32156,336$ & 8924,992 & $-3,836$ & 0,013 \\
\hline
\end{tabular}

Sumber : Data Olahan (2020)

Berdasarkan model tersebut di atas, dijumpai besarnya nilai konstanta 31390.396 berarti bahwa dengan asumsi variabel lain tidak ada (nol), besarnya pengeluaran konsumsi berbagai jenis bukan makanan masyarakat perkotaan lebih besar dari konsumsi bukan makanan masyarakat pedalaman Rp.2.248.000. Dan juga lebih besar dari konsumsi bukan makanan masyarakat pesisir sebesar Rp.1.376,250. Dengan demikian, pada saat pendapatan, aktivitas ekonomi, dan anggota keluarga tidak ada (nol), konsumsi bukan makanan masyarakat pedalaman berkurang sebesar Rp.621256. Demikian juga dengan konsumsi bukan makanan masyarakat yang tinggal di pesisir, pada saat variabel lain konstan, besarnya pengeluaran bukan makanan masyarakat pesisir berkurang Rp.789854. Hal ini mengindikasikan 
bahwa pengeluaran konsumsi bukan makanan masyarakat perkotaan lebih besar dibandingkan masyarakat yang tinggal di wilayah pesisir dan pedalaman Kabupaten Labuhanbatu. Koefisien variabel pendapatan (PDPT) sebesar $-0,523$ yang berarti bahwa kenaikan pendapatan Rp. 1.000 akan meningkatkan pengeluaran konsumsi untuk jenis pengeluaran bukan makanan sebesar Rp.523. Koefisien variabel aktivitas ekonomi (AKE) sebesar 125,121 yang berarti bahwa dengan bertambahnya 1 jam waktu kerja dalam 1 bulan justru akan mengurangi pengeluaran konsumsi bukan makanan sebesar Rp.115.121. Demikian halnya dengan anggota rumah tangga (ART) dijumpai koefisien sebesar -6214.256 yang berarti bahwa dengan bertambahnya anggota keluarga 1 orang, justru akan mengurangi pengeluaran konsumsi bukan makanan sebesar Rp. 6214.256

\section{Pembuktian Hipotesis}

Sebelum melakukan pembuktian hipotesis sebagaimana yang telah dirumuskan pada bab sebelumnya, terlebih dahulu akan dilakukan uji kesesuaian model (Goodness of Fit) atau uji $\mathrm{R}^{2}$. Sebagaimana hasil estimasi yang dilakukan (lampiran 4) dijumpai koefisien korelasi (R) dan koefisien determinasi $\quad\left(\mathrm{R}^{2}\right) \quad$ sebagaimana ditampilkan pada tabel 3 di bawah ini

Tabel 4 Uji Goodness of Fit Model Konsumsi Makanan dan Model Konsumsi Bukan Makanan

\begin{tabular}{ccc}
\hline NILAI & $\begin{array}{c}\text { MODEL KONSUMSI } \\
\text { MAKANAN }\end{array}$ & $\begin{array}{c}\text { MODEL KONSUMSI } \\
\text { BUKAN MAKANAN }\end{array}$ \\
\hline $\mathrm{R}$ & $0,822^{\mathrm{a}}$ & $0,786^{\mathrm{a}}$ \\
$\mathrm{R}^{2}$ & 0,835 & 0,724 \\
$\mathrm{R}^{2 \mathrm{Adj}}$ & 0,813 & 0,768 \\
\hline
\end{tabular}

a Predictors: (Constant), D2, ART, AKE, D1, PDPT

Sumber : Data Olahan (2020)

Berdasarkan hasil estimasi yang ditunjukkan pada tabel di atas, terlihat bahwa nilai R-Square model konsumsi makanan sebagai variabel dependen sebesar 0,822 yang berarti variasi kemampuan variabel pendapatan (PDPT), aktivitas ekonomi (AKE), dan anggota rumah tangga (ART) serta variabel dummy, dalam menjelaskan besarnya konsumsi makanan petani kelapa sawit di Kabupaten Labuhanbatu sebesar 82,2 persen, sisanya hanya sebesar 17,7 persen dijelaskan oleh variabel lain yang tidak dimasukkan dalam model.

Demikian juga dengan model kedua, yang memasukkan variabel pengeluaran konsumsi bukan makanan sebagai variabel dependen. Nilai RSquare di jumpai sebesar 0,786 yang berarti variasi kemampuan variabel pendapatan (PDPT), aktivitas ekonomi (AKE), dan anggota rumah tangga (ART) serta variabel dummy, dalam menjelaskan besarnya pengeluaran konsumsi bukan makanan petani kelapa sawit di Kabupaten Labuhanbatu sebesar 78,6 persen, sisanya hanya sebesar 21,4 persen dijelaskan oleh variabel lain yang tidak dimasukkan dalam model

Sebagaimana yang telah dirumuskan pada bab sebelumnya, bahwa pengujian secara parsial (individu) dilakukan dengan membandingkan nilai t-hitung dengan 
nilai t-tabel. Selain itu juga dilihat berdasarkan nilai signifikansi (sig.) pada hasil estimasi (lampiran 4 dan 5).

Pada jumlah sampel $(\mathrm{n})=77$, variabel bebas $(\mathrm{k})=5$. Koutsoyiannis, (1981) menjelaskan bahwa besarnya $\mathrm{k}$ adalah variabel bebas termasuk konstanta. Dengan demikian $\mathrm{k}=6$, dijumpai Degree of Freedom $(\mathrm{DF})=77$ $-6=71$. Pada DF $=71$ dijumpai t-tabel pada pengujian dua ekor; $\alpha=0,01$ sebesar 1.66660, pada $\alpha=0,05$ sebesar 2.38002 dan pada $\alpha=0,10$ sebesar 1.29359

\section{Uji Parsial Model Konsumsi Makanan}

Sebagaimana hasil estimasi nilai t-hitung yang ditampilkan pada tabel diatas bahwa variabel pendapatan (PDPT) dijumpai t-hitung sebesar $10,845>2,38002$ berarti bahwa variabel pendapatan berpengaruh signifikan terhadap konsumsi petani kelapa sawit Kabupaten Labuhanbatu pada $\alpha=0,01$. Hal ini diperkuat dengan nilai sig. $=0,000$ yang berada dibawah batas toleransi 0,01 .

Variabel aktivitas ekonomi (AKE) dijumpai t-hitung sebesar 2,782 > 2,38002 berarti bahwa variabel aktivitas ekonomi berpengaruh positif dan signifikan terhadap konsumsi makanan petani kelapa sawit Kabupaten Labuhanbatu pada $\alpha=0,05$. Hal ini diperkuat dengan nilai sig. $=0,014$ yang berada dibawah batas toleransi 0,05 .

Variabel anggota rumah tangga (ART) dijumpai t-hitung sebesar 3,078 $>$ 2,38002 berarti bahwa variabel anggota rumah tangga berpengaruh positif dan signifikan terhadap konsumsi makanan petani kelapa sawit Kabupaten Labuhanbatu pada $\alpha=0,01$. Hal ini diperkuat dengan nilai sig. = 0,045 yang berada dibawah batas toleransi 0,05 .

Nilai t-hitung variabel dummy masyarakat pesisir sebesar 1,519< 1.293 berarti bahwa konsumsi makanan petani kelapa sawit yang tinggal di pesisir tidak signifikan berbeda dengan petani kelapa sawit yang tinggal di daerah daerah perkotaan Kabupaten Labuhanbatu

Sementara nilai t-hitung variabel dummy masyarakat pedalaman sebesar $3,836>2,38002$ berarti bahwa konsumsi makanan petani kelapa sawit yang tinggal di pedalaman signifikan berbeda dengan masyarakat yang tinggal di daerah daerah perkotaan Kabupaten Labuhanbatu

Tanaman kelapa sawit mempunyai beberapa keunggulan jika dibandingkan tanaman lainnya. Keunggulan tersebut dapat dilihat dari segi produktivitas minyak kelapa sawit yang tinggi, masa produksi kelapa sawit yang cukup panjang hingga 25 tahun juga akan mempengaruhi ringannya biaya produksi yang akan dikeluarkan petani. Dari segi hama dan penyakit tanaman kelapa sawit termasuk tanaman yang tahan terhadap hama dan penyakit jika dibandingkan dengan tanaman lain (Fauzi et al., 2012).

Dari model ini dapat disimpulkan bahwa pengeluaran konsumsi masyarakat perkotaan jauh lebih baik dibandingkan dengan pengeluaran konsumsi masyarakat yang tinggal di wilayah pesisir dan pedalaman. Dari segi koefisien regresi, pendapatan kepala rumah tangga tetap menjadi variabel utama yang mempengaruhi pengeluaran konsumsi makanan maupun bukan makanan petani kelapa sawit di Kabupaten Labuhanbatu.

Hasil regresi ditemukan bahwa pada model konsumsi makanan semua variabel eksplanatori berpengaruh positif dan signifikan, sementara pada model pengeluaran konsumsi bukan semua variabel eksplanatori berpengaruh negatif. Dengan demikian dapat disimpulkan bahwa dengan 
meningkatnya konsumsi makanan, petani kelapa sawit di Labuhanbatu terpaksa harus mengurangi dan menunda pengeluaran konsumsi bukan makanan. Penambahan dalam konsumsi erat kaitannya dengan tingkat pendapatan, variabel lain yang turut meningkatkan besarnya konsumsi adalah aktivitas ekonomi dan jumlah anggota rumah, serta wilayah tempat tinggal tersebut (Dianawati \& Mustika 2016).

\section{PENUTUP}

\section{Kesimpulan}

Berdasarkan hasil penelitian yang telah dipaparkan pada bab sebelumnya, maka dapatlah ditarik beberapa kesimpulan, sebagai berikut:

1. Spesifikasi model yang digunakan dalam penelitian ini sudah cukup baik, hal ini telah dibuktikan dengan terbebasnya model dari pelanggaran asumsi klasik. Setelah dilakukan pengujian terhadap variabel-variabel eksplanatori yang digunakan tidak berkorelasi yang kuat satu sama lainnya, selain itu data juga bersifat homokedastis. Kelayakan spesifikasi model juga dibuktikan dengan nilai R-Square kedua model yang cukup tinggi.

2. Dari model LSDV dapat disimpulkan keunikan model ini dalam menjelaskan perbedaan konsumsi petani kelapa sawit yang tinggal di daerah perkotaan dengan yang tinggal di wilayah pesisir maupun pedalaman Kabupaten Labuhanabtu. Dari model ini dapat disimpulkan bahwa pengeluaran konsumsi masyarakat perkotaan jauh lebih baik dibandingkan dengan pengeluaran konsumsi masyarakat yang tinggal di wilayah pesisir dan pedalaman. Dari segi koefisien regresi, pendapatan kepala rumah tangga tetap menjadi variabel utama yang mempengaruhi pengeluaran konsumsi makanan maupun bukan makanan petani kelapa sawit di Kabupaten Labuhanbatu.

3. Hasil regresi ditemukan bahwa pada model konsumsi makanan semua variabel eksplanatori berpengaruh positif dan signifikan, sementara pada model pengeluaran konsumsi bukan semua variabel eksplanatori berpengaruh negatif.

4. Secara statistik, variabel pendapatan, aktivitas ekonomi kepala keluarga, jumlah anggota rumah tangga, dan wilayah tempat tinggal keluarga signifikan mempengaruhi besarnya konsumsi petani kelapa sawit, baik dari pengujian secara parsial maupun pengujian secara simultan. Bila dibandingkan dengan pengujian secara parsial, pengaruh variabelvariabel tersebut secara simultan lebih tinggi. Sehingga kesimpulan dari uji inferen statistik menerima hipotesis alternative dan menolak hipotesis nol.

\section{Saran}

Pada bagian akhir penelitian ini, penulis ingin menyarankan beberapa hal sebagai implikasi dari penelitian ini, yaitu:

1. Pemerintah daerah perlu melakukan langkah strategis guna menanggulangi masalah pengeluaaran yang begitu tinggi bagi masayarakat desa di Kabupaten Labuhanbatu, Pemerintah daerah dan pihak-pihak terkait perlu meningkatkan fasilitas pelayanan publik terutama yang diprioritaskan bagi masyarakat desa yang berada di 
wilayah pesisir dan wilayah pedalaman Kabupaten Labuhanbatu, diantaranya rencana penanggulangan dapat dilakukan dengan proses indentifikasi keluarga petani kelapa sawit, dengan meningkatkan budaya wirausaha masyarakat melalui pemberian modal kerja bagi sektorsektor produktif.

2. Sebaik juga menambah dan memperbaiki sarana transportasi (seperti; jalan, jembatan, dan sarana tranportasi umum) untuk mempermudah akses keluarga petani kelapa sawit terutama yang berada di wilayah pesisir dan pedalaman dengan pusat pasar dan pusat pemerintahan. Meningkatkan sarana dan kualitas pendidikan (seperti; sekolah, dan peningkatan kualitas guru), dan juga memberikan pelayanan pendidikan gratis kepada anak-anak dari keluarga petani kelapa sawit.

3. Salah satu contoh keberhasilan pembangunan ekonomi yang mengakar pada masyarakat sebagaimana yang dilakukan oleh Muhammad Yunus dari Banglades dengan mengandalkan Grameen Bank telah berhasil membangun ekonomi masyarakat Banglades dari tingkat yang paling rendah. Keberhasilan yang mereka capai sepatutnya dijadikan rujukan dalam pembangunan penyediaan sarana dan prasarana di wilayah pesisir dan pedalaman di Kabupaten Labuhanbatu.

\section{DAFTAR PUSTAKA}

Dianawati, W., \& Mustika, M., D., S. (2016). Analisis Pengaruh Pengeluaran Konsumsi Pedagang Canang di Pasar Tradisional Kecamatan Denpasar Barat. E-Jurnal EP Unud, 6(5).

Fauzi, Y., Widyastuti, Y., E., Satyawibawa, I., \& Paeru, R. H. (2012). Kelapa sawit. Penebar Swadaya Grup.

Hanum, N. (2017). Analisis Pengaruh Pendapatan Terhadap Perilaku Konsumsi Mahasiswa Universitas Samudra di Kota Langsa. Jurnal Samudra Ekonomika, 1(2), 107-116.

Mayasari, D., Satria, D., \& Noor, I. (2018). Analisis Pola Konsumsi Pangan Berdasarkan Status IPM di Jawa Timur. Jurnal Ekonomi dan Pembangunan Indonesia, 18(2), 191-213.

Prasetyoningrum, F., Rahayu, E., S., \& Marwanti, S. (2016). Analisis pola konsumsi rumah tangga petani jagung di Kabupaten Grobogan. Agric, 28(1), 41-54.

Tamawiwi, K., N., Katiandagho, T., R., Rengkung, L., R., \& Lolowang, T., F. (2015, May). Pola Konsumsi Masyarakat Miskin di Desa Tiwoho Kecamatan Wori Kabupaten Minahasa Utara. In $\operatorname{COCOS,~6(9).~}$

Wahyuni, S. (2013). Teori Konsumsi Dan Produksi Dalam Perspektif Ekonomi Islam. AKUNTABEL, 10(1).

Yusty, G., T., Zakaria, W., A., \& Adawiyah, R. (2014). Analisis pola konsumsi ubi kayu dan olahannya pada rumah tangga di Kota Bandar Lampung. Jurnal Ilmu-Ilmu Agribisnis, 2(2), 190195. 